Article

\title{
Remote Monitoring of Ground Motion Hazards in High Mountain Terrain Using InSAR: A Case Study of the Lake Sarez Area, Tajikistan
}

\author{
Stephen Grebby ${ }^{1, *(D)}$, Andrew Sowter ${ }^{2}$, David Gee ${ }^{2}$, Ahmed Athab ${ }^{2}$, Betsabé De la Barreda-Bautista ${ }^{3}$, \\ Renoy Girindran ${ }^{3}$ and Stuart Marsh ${ }^{1}$ (D) \\ 1 Nottingham Geospatial Institute, University of Nottingham, Nottingham NG7 2TU, UK; \\ Stuart.Marsh@nottingham.ac.uk \\ 2 Terra Motion Limited, Ingenuity Centre, Nottingham NG7 2TU, UK; \\ Andrew.Sowter@terramotion.co.uk (A.S.); David.Gee@terramotion.co.uk (D.G.); \\ Ahmed.Athab@terramotion.co.uk (A.A.) \\ 3 School of Geography, University of Nottingham, Nottingham NG7 2RD, UK; \\ Betsabe.Delabarreda@nottingham.ac.uk (B.D.1.B.-B.); Renoy.Girindran@nottingham.ac.uk (R.G.) \\ * Correspondence: Stephen.Grebby@nottingham.ac.uk
}

check for updates

Citation: Grebby, S.; Sowter, A.; Gee, D.; Athab, A.; Barreda-Bautista, B.D.1.; Girindran, R.; Marsh, S. Remote Monitoring of Ground Motion Hazards in High Mountain Terrain Using InSAR: A Case Study of the Lake Sarez Area, Tajikistan. Appl. Sci. 2021, 11, 8738. https://doi.org/ 10.3390/app11188738

Academic Editor: Michael Tsesarsky

Received: 22 July 2021

Accepted: 17 September 2021

Published: 19 September 2021

Publisher's Note: MDPI stays neutral with regard to jurisdictional claims in published maps and institutional affiliations.

Copyright: (C) 2021 by the authors. Licensee MDPI, Basel, Switzerland. This article is an open access article distributed under the terms and conditions of the Creative Commons Attribution (CC BY) license (https:// creativecommons.org/licenses/by/ $4.0 /)$.

\begin{abstract}
High mountain terrains, with steep slopes and deep valleys, are generally challenging areas to monitor using satellite earth observation techniques since the terrain creates perspective distortions and differences in illumination that can occlude or obfuscate a significant proportion of the land. This is particularly prominent in synthetic aperture radar (SAR) data, where the oblique geometry can result in large areas of layover and shadow, which must be excluded from any analysis. Interferometric SAR (InSAR) is an established technique for monitoring ground motion and this study assesses its potential for geohazard monitoring in mountainous areas using Lake Sarez in Tajikistan as a case study, applying SAR data from the Sentinel-1 mission. It is shown that, although the effect of layover and shadow is severe, a judicious combination of ascending and descending satellite passes is still capable of surveying $88 \%$ of the land surface. It is also demonstrated that, through the use of an advanced InSAR technique (the APSIS ${ }^{\text {TM }}$ Intermittent Small Baseline Subset technique), near-complete coverage of ground motion measurements is possible, despite intermittent snow cover. Moreover, this is achieved without the need for ground control, which can be hazardous to establish in such areas. It is concluded that a combination of satellite passes and advanced InSAR techniques greatly facilitates the remote monitoring of ground motion hazards in high mountain areas.
\end{abstract}

Keywords: geohazards; InSAR; ground motion; landslides; Sentinel-1; Lake Sarez

\section{Introduction}

High mountain areas are unsurprisingly prone to a number of geohazards associated with steep slopes, such as rockfalls, debris flows, landslides, avalanches, and floods. These hazards impact infrastructure and human activity in those areas [1], and their occurrence can have an enormous human and economic cost. For example, in 2010, a rockslide dammed the Hunza River in Pakistan submerging several villages and $22 \mathrm{~km}$ of the strategic Karakoram Highway between Pakistan and China [2]. The flood was disastrous for the infrastructure of the mountain valleys and affected millions of people in the irrigated plains of Punjab and Sindh [3]. The economic impact of this disaster was estimated at almost US\$4 billion [4].

Mountainous terrain can be difficult to access and hazardous to work in, and so remote sensing has a major role to play in the assessment and continued monitoring of the risks posed by geohazards in these settings [5]. The provision of free earth observation (EO) satellite data that is being routinely gathered over the land surface, such as that provided by the Copernicus programme of the European Union (https:/ / www.copernicus.eu (accessed 
on 28 June 2021)), means that there is a basis for cost-effective monitoring programmes over such regions that could be sustained for the foreseeable future. Furthermore, the development of novel EO data processing techniques that are capable of providing dense sets of measurements without the need for ground surveys means that such monitoring can be undertaken safely and without any of the delays associated with establishing ground-based monitoring networks.

An EO technique that is becoming increasingly important in the monitoring of mass movements on slopes is interferometric synthetic aperture radar (InSAR), where its application could improve risk awareness and provide early warning of impending catastrophic slope failures in vast, inaccessible, or otherwise unmonitored regions [6]. However, one of the major disadvantages regarding the application of InSAR surveys to mountainous areas is that the extreme topography can result in differences in illumination and perspective distortions between foreslopes and backslopes, which can subsequently hinder the interpretation. This is a particular problem for oblique-looking synthetic aperture radar (SAR) sensors, where foreshortening, layover, and shadow effects are prevalent in mountainous terrain. This is evident in a study of the 2008 Wenchuan earthquake in China using SAR data, where Sowter [7] found that almost 50\% of the ground area was obscured by layover and shadow. Similarly, in a landslide monitoring study of a mountainous region of China, Sun et al. [8] found as much as 50\% of the area was affected by geometric distortions in data acquired using some SAR sensors. Layover and shadow effects were also responsible for an underestimation of active landslides in an InSAR study of a mountainous area of California and Oregon (USA) by Zhao et al. [9]. Further problems that are capable of affecting conventional InSAR surveys of mountain regions include the impersistent scattering characteristics of natural land cover (e.g., vegetation) and seasonal snow cover, which can also limit the density of ground motion measurements that can be obtained due to the decorrelation of the radar signal $[10,11]$.

The current availability of Copernicus Sentinel-1 C-band SAR data, with high temporal and spatial resolution, and advanced InSAR processing techniques promise to offer an enhanced potential for the routine and ubiquitous remote monitoring of inaccessible areas. Nevertheless, in order to help fully exploit this potential, feasibility assessments are needed to explore the limitations and the enhanced opportunities afforded in terms of obtaining sufficient spatial coverage of ground motion measurements. Accordingly, the aim of this study is to evaluate the feasibility of Sentinel-1 InSAR for monitoring ground motion in high mountain terrain, based on a case study of the Lake Sarez area in Tajikistan. A similar assessment with respect to the effect of geometric distortions has previously been undertaken over the Zhouqu area in China, based on ALOS and ENVISAT SAR data acquired with opposing viewing geometries [8]. However, the objective of the current study is to assess the constraints on the efficacy of Senetinel-1 InSAR posed by both geometric distortions and decorrelation due to land cover, and to explore ways in which these could be mitigated through the choice of both viewing geometry and InSAR processing technique. Lake Sarez is a famous 'quake lake' threatened by a number of landslide hazards on several of the steep slopes that surround it. This site was selected as it has been widely studied in the past, and the application of new or improved remote sensing techniques would undoubtedly help supplement the knowledge of the risks around the lake and in the wider area [12].

\section{Study Area and Data}

\subsection{Study Area}

The Lake Sarez study site is located in the Rushon District of Gorno-Badakhshan province, Tajikistan, within the Pamir Mountains (Figure 1). The Pamir Mountains are part of the Himalaya-Hindu Kush-Karakorum-Pamir-Tian Shan mountain belt formed at the Indian-Eurasian collisional plate boundary [13]. 

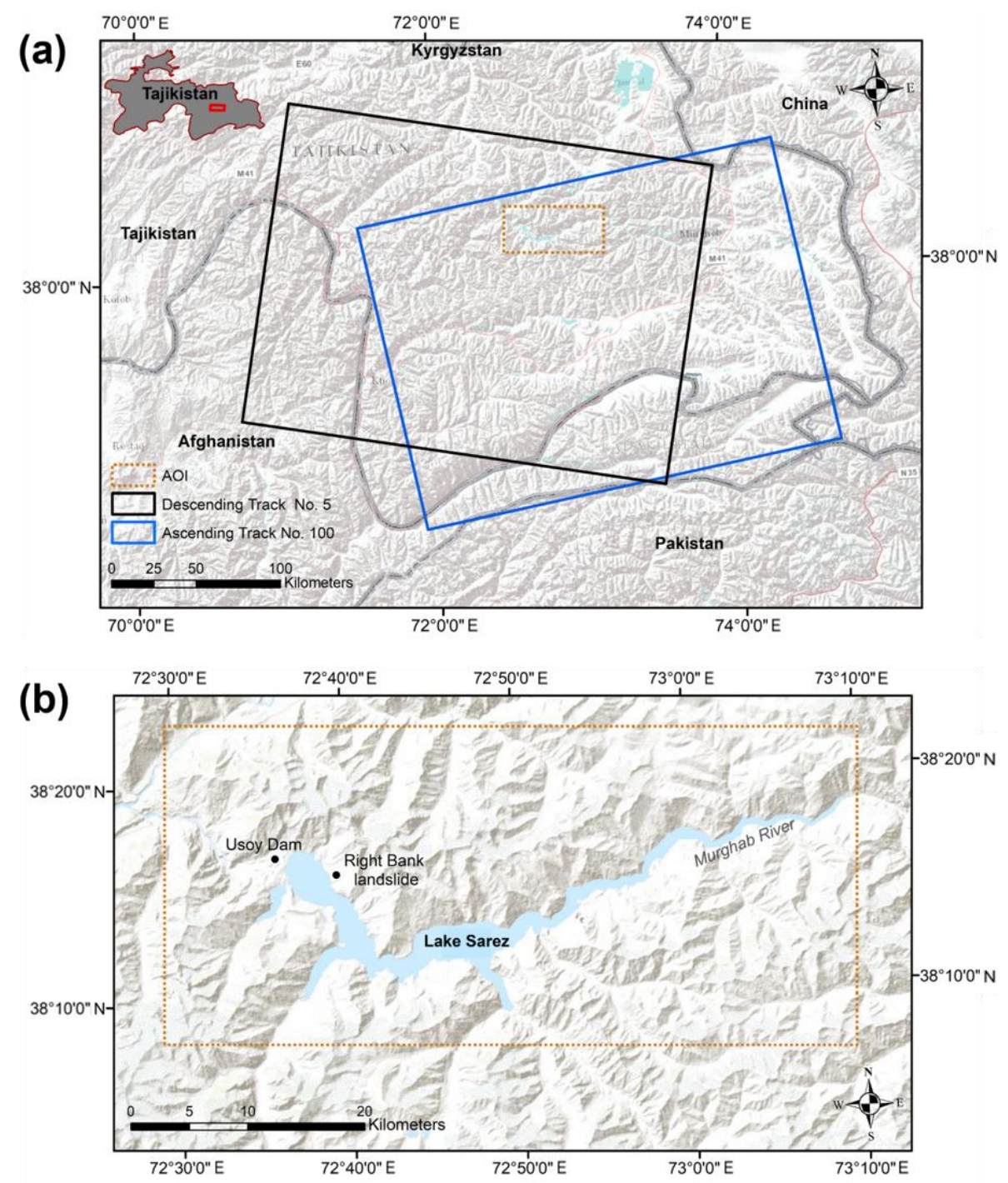

Figure 1. The location of Lake Sarez. (a) The coverage of the ascending and descending Sentinel-1 frames, and (b) study area of interest (AOI).

The Western Pamir and the Eastern Pamir are well divided by their physiographic characteristics. For instance, the Eastern Pamir is characterised by its mountainous plateau, whereas the Western Pamir, containing Lake Sarez, is highly mountainous with deep valleys [14]. Lake Sarez has a continental climate, mainly influenced by the Westerlies, that is responsible for the precipitation in winter and dry summers. Temperatures are moderately warm in summer and moderately cold in winter, typically ranging from $-10^{\circ} \mathrm{C}$ to approaching $30^{\circ} \mathrm{C}$. Precipitation in this area decreases towards the Eastern Pamir due to the interception of precipitation in the Western peaks. These climatic conditions, in combination with the topography, result in mountainous vegetation, arid vegetation, shrublands, steppe, and semidesert ecosystems [15].

The Lake Sarez region lies within the Sarez-Karakul fault zone [16], resulting in extensive fracturing of the carboniferous rock mass (sandstone, schist, quartzite) of the Sarez Formation [17]. The lake itself is situated approximately $3250 \mathrm{~m}$ above sea level, is $75 \mathrm{~km}$ long, and contains $\sim 17 \mathrm{~km}^{3}$ of stored water. Its surrounds are characterised by the steep topography of the peaks of the Pamirs, which rise to more than $2300 \mathrm{~m}$ above the level of the lake. As a result of the high degree of fracturing, mass movements in the form of rockfalls and talus deposits are frequent along the slopes, particularly on the right bank of the Murghab River valley [17]. 
The region is seismically active, with $M>6$ earthquakes occurring approximately every 10 years [18]. Lake Sarez was formed when a landslide dammed the Murghab River following the Sarez-Pamir Earthquake $\left(M_{w} \sim 7.3\right)$ on 18th February 1911 [19]. The landslide dam, known as Usoy Dam (see Figure 1b), is the largest and highest natural dam in the world, and concerns have been raised with regards to the risk it could pose should it be breached [20]. If the dam were to fail, a flood would be catastrophic to the 5.5 million people living downstream in the Amu Darya river valley, which flows through Tajikistan, Afghanistan, Turkmenistan, and Uzbekistan. The three main concerns regarding dam failure are seismic shaking, seepage, and a landslide creating a displacement wave within the lake [21]. The latter is regarded as most likely given that nearly all the surrounding slopes are susceptible to landslides due to their steep, highly fractured slopes, which could be triggered by an earthquake. Previously, in 1968, a landslide induced a 2-m-high wave across the lake [22-24]. At present, a $3 \mathrm{~km}^{3}$ partially detached rock mass on the right bank (known as the Right Bank landslide; Figure $1 \mathrm{~b}$ ) is of particular concern. If triggered, the sliding or collapse of this rock mass into the lake could induce a deadly megatsunami causing water to overtop the dam [25], as has previously occurred at the Vajont Dam, Italy in 1963 [26].

\subsection{InSAR for Remote Ground Motion Monitoring}

InSAR is a geodetic method of measuring changes in the Earth's surface height. It is based upon interferometry, where the interference of electromagnetic waves from two SAR acquisitions is utilised to derive precise changes in elevation [27]. Deformation studies have been revolutionised by differential InSAR (DInSAR) since the first detection of differential motion [28]. However, it is widely acknowledged that phase decorrelation (or incoherence) is a significant limitation of InSAR, which severely affects the spatial distribution and density of measurements outside of urbanised and arid terrain with sparse vegetation cover [29]. This effect is most prevalent in higher frequency radar bands, such as C-band, where incoherence is pervasive over agricultural fields, forests, semi-natural areas, and wetlands [30]. The poor density of InSAR measurements in rural areas in some extents can be mitigated through the deployment of artificial corner reflectors, installed in situ [31], although in steep, inhospitable terrain this can be dangerous and laborious over vast areas and further requires routine maintenance to ensure that their integrity is guaranteed over the entire monitoring period, including during times of snow cover. Logistically and administratively, it can slow the start of a monitoring programme and, as it is not possible to install them retrospectively, it excludes the possibility of exploiting historical observations contained within archived datasets [10].

The interaction of radar (particularly C-band) with snow is complex [32] and can result in significant interferometric decorrelation. Therefore, it is important to consider how this may affect the monitoring capabilities in high mountain areas and if any mitigating action can be taken. In permafrost areas in the high Arctic, where the ground is covered in snow for long periods, InSAR can prove almost impossible to use throughout an entire year due to prolonged incoherence and, to mitigate against this, artificial corner reflectors usually need to be installed in the field [33]. Lake Sarez falls in the 3000-4000 m elevation zone in the Himalayas where snow generally covers less than $40 \%$ of the land area throughout the year; there is a large inter-annual variability, with up to $60 \%$ cover in February to March, falling to almost nothing from April to August [34]. Nonetheless, these conditions could still significantly restrict the capabilities of InSAR techniques that require persistently high coherence throughout the entire period of observation. The challenge of obtaining a dense set of ground motion measurements has been demonstrated through previous InSAR surveys of the Lake Sarez area [35,36], which have been attempted using the persistent scatterers InSAR (PSInSAR) [37] and Small Baseline Subset (SBAS) [38] algorithms.

With coverage limited due to the effects associated with the extreme topography, maximising the density of measurements is especially important for capturing both largeand small-scale mass movements to enable a comprehensive assessment of hazards in the 
Lake Sarez area. In addition to considering multiple SAR imaging geometries, this may also be achieved using advanced InSAR techniques, such as the Intermittent Small Baseline Subset (ISBAS) algorithm $[39,40]$. The ISBAS algorithm has been demonstrated to greatly increase the density and spatial distribution of measurements at millimetre-level accuracy over bare soils and vegetated surfaces [41], which it achieves through a modification of the SBAS algorithm to consider the intermittent nature of coherence over dynamic land cover types. A number of comparative studies of PSInSAR survey point densities over different types of land cover classes have been attempted over the UK [42] and Nepal [43]. Although for urban classes, the density of measurements can be very high at around 1800 points per $\mathrm{km}^{2}$ using C-band SAR data, this rapidly falls to 300 or less for bare land, and 100 or less over the sparse mountain vegetation typical of this study area. In comparison, the ISBAS method can achieve 4-26 times more coverage than PSInSAR [44], routinely achieving more than 2200 pixels per $\mathrm{km}^{2}$ over the entire rural landscape when using Sentinel-1 and a survey resolution of $20 \mathrm{~m}$. Moreover, as an intermittent coherent pixel technique, ISBAS does not rely on pixels being of permanently high coherence throughout the full period of observations, but instead merges observations of opportunity in each interferogram as they occur. Accordingly, this characteristic could help to readily mitigate the impact of seasonal snow, provided that the cover is neither ubiquitous nor sustained.

Another advantage of the ISBAS algorithm, and a consequence of the high density of measurements that can be achieved, is the ability to map ground motion without the use of ground control, such as GPS receivers and artificial corner reflectors. This has been demonstrated for a variety of disaster risk reduction applications associated with slope failures, such as landslide inventory mapping [45,46] and tailings dam monitoring [47]. The ability to monitor ground motion without any requirements for ground control or repeated field visits is particularly advantageous in inaccessible mountainous terrain. Although the Lake Sarez area is equipped with various sensors, including GPS stations, as part of a remote monitoring and early-warning system [35], these only provide a sparse set of discrete point measurements. Therefore, the detailed and widespread coverage provided by satellite InSAR has the potential to greatly complement the monitoring of the area.

\subsection{Data}

Sentinel-1 is an imaging SAR mission of the Copernicus programme that provides continuous, all-weather, day-night imagery for the C-band. It potentially images all global landmasses at regular intervals, at least every 12 days ( 6 days over Europe), with a typical resolution of $20 \mathrm{~m}$. The mission consists of two satellites, the first of which was launched in 2014, followed by the second in 2016. Practically, this means that there is generally a good archive of data going back around 4-5 years from the present day. The free, full, and open data policy adopted for the Copernicus programme means that access to the imagery is freely available to all commercial, academic and institutional users. Accordingly, Sentinel-1 provides an excellent basis for a sustainable and cost-effective ground motion monitoring system anywhere around the world.

Over the Lake Sarez study area, two stacks of Sentinel-1 imagery were identified for the period September 2017-September 2019. The stacks comprised 60 SAR images acquired from ascending track $\mathrm{N}^{\circ} 100$ and 58 images from descending track $\mathrm{N}^{\circ} 5$. The temporal spacing of the images from each track was 12 days. The data are provided by the European Space Agency and were obtained from the Copernicus Open Access Hub (https://scihub.copernicus.eu/dhus/\#/home (accessed on 27 November 2019)). Data products in the Interferometric Wide format were selected for processing. The footprint of each track and frame is shown in Figure 1a.

The processing of the SAR data was supported using a $90 \mathrm{~m}$ Shuttle Radar Topography Mission (SRTM) digital elevation model (DEM) [48]. Created in 2000, the SRTM DEM was used to remove the topographic phase from the interferograms and help identify areas affected by geometric distortions. Additionally, the SRTM DEM was used to geocode all ground motion outputs to a Universal Transverse Mercator (UTM) projection. 


\section{Methods}

A set of differential interferograms was first generated for each Sentinel-1 stack using a 180-day limit on the temporal baseline, $150 \mathrm{~m}$ on the orbital baseline, and a multi-look factor of $7 \times 2$ pixels (Table 1 ). In doing so, the topographic phase was simulated and removed with the aid of the SRTM DEM. The resultant pixel spacing in ground-range is approximately $20 \mathrm{~m}$.

Table 1. InSAR processing parameters.

\begin{tabular}{|c|c|c|c|c|c|c|c|c|}
\hline Geometry & $\begin{array}{l}\text { Angle of } \\
\text { Incidence at } \\
\text { AOI Centre }\end{array}$ & $\begin{array}{c}\text { Max. } \\
\text { Orbital } \\
\text { Baseline (m) }\end{array}$ & $\begin{array}{c}\text { Max. } \\
\text { Temporal } \\
\text { Baseline } \\
\text { (days) }\end{array}$ & $\begin{array}{l}\text { Multi-Look } \\
\text { (Azimuth: } \\
\text { Range) }\end{array}$ & $\begin{array}{l}\text { Coherence } \\
\text { Threshold }\end{array}$ & $\begin{array}{l}\mathrm{N}^{\circ} \text { of Inter- } \\
\text { ferograms }\end{array}$ & $\begin{array}{c}\text { Interferogram } \\
\text { Threshold }\end{array}$ & $\begin{array}{c}\text { Reference } \\
\text { Point } \\
\text { (lat/long) }\end{array}$ \\
\hline Ascending & $\sim 37^{\circ}$ & 150 & 180 & $7: 2$ & 0.45 & 710 & 350 & $38.320^{\circ} /$ \\
\hline Descending & $\sim 35^{\circ}$ & 150 & 180 & $7: 2$ & 0.45 & 701 & 350 & $72.612^{\circ}$ \\
\hline
\end{tabular}

Each set of differential interferograms were processed separately utilizing two different InSAR approaches: the first using a conventional SBAS approach, following Berardino et al. [38]; and the second using the ISBAS approach. The ISBAS processing was undertaken using the Advanced Pixel System using Intermittent SBAS (APSIS ${ }^{\mathrm{TM}}$ ) method (developed by Terra Motion Limited), which is an implementation of the ISBAS approach of Sowter et al. [39], but with additional capability for higher resolution processing, full stereo InSAR analysis and the ability to simulate the imaging geometry-important when monitoring areas of extreme topography. The processing for the two approaches is almost the same, except that the SBAS processing considers only pixels with consistent coherence throughout the entire stack, whereas the enhanced ISBAS processing considers pixels that satisfy the coherence threshold in a minimum number of interferograms-in doing so, permitting the analysis of features that are intermittently coherent. The optimum interferograms threshold can be identified based on an empirical relationship between the standard error of the ISBAS velocity solutions and the number of interferograms [44]. In this case, the minimum number of interferograms for the ISBAS processing was set as 350 (see Table 1), meaning that the maximum standard error was expected to be $0.59 \mathrm{~mm} /$ year.

Average velocities and time-series of ground motion for the entire period of SAR observations were then computed relative to a reference point (located at $38.320^{\circ} \mathrm{N}, 72.612^{\circ} \mathrm{E}$ ) located on a mountain ridge $5 \mathrm{~km}$ north of Lake Sarez. The same reference point was used for each InSAR method, and it was assumed to be stable based on its location away from potentially unstable slopes and its high temporal coherence. Providing measurements at $\sim 20 \mathrm{~m}$ resolution, these ground motion products were computed for each satellite track in an attempt to maximise the potential to identify potential ground motion hazards in the Lake Sarez area.

Geometric distortions occur in the Sentinel-1 imagery, which are generated by topographic features on the ground and are a consequence of the side-looking geometry and the SAR operational parameters (e.g., incidence angle). These manifest as areas of layover and shadow that essentially obscure measurement of the affected areas (Figure 2). These effects are not a consequence of the choice of the InSAR processing technique but are an inherent limitation associated with all InSAR methods. However, as alluded to above, the area affected by layover and shadow can be extensive in mountainous areas [7] and need to be excluded from any InSAR analysis [49]. As part of the processing, a full simulation of the SAR imaging geometry is performed using the SRTM DEM and the satellite orbit parameters. The output of this is layover and shadow masks that delineate the effect that the mountainous topography has upon the ability to monitor ground motion through satellite InSAR surveys. 

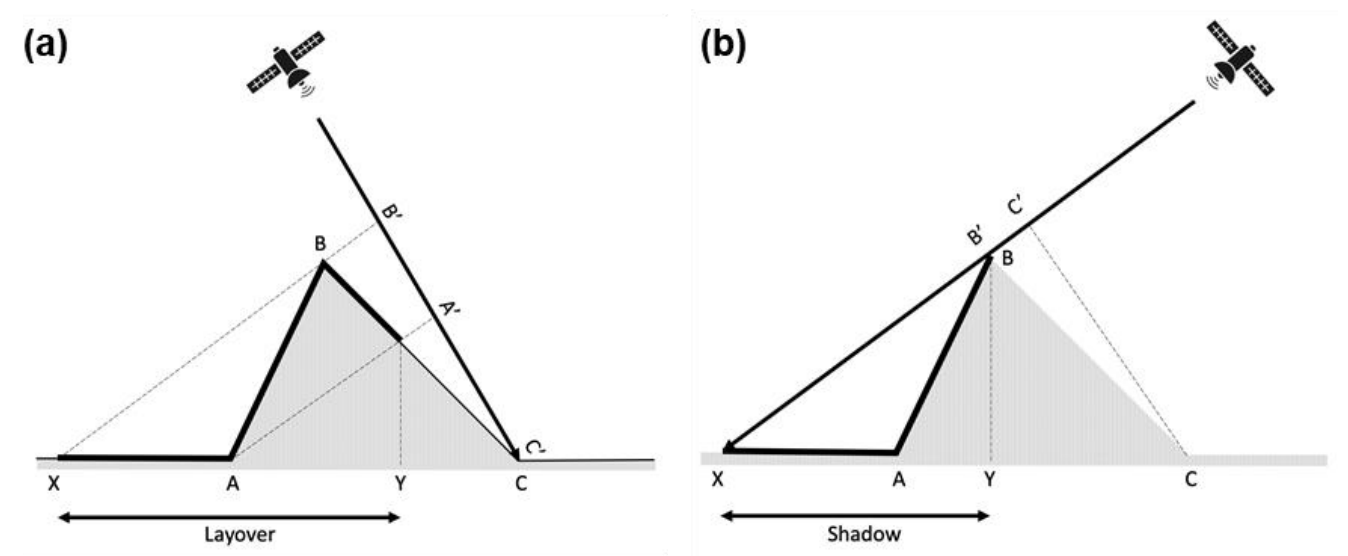

Figure 2. (a) Layover occurs in areas of steep topography when the peak of a feature (B) is actually closer to the radar than features on the slopes. This can result in a large area where reflections are superimposed (shown as a thick black line); in this scenario, the ground area between $\mathrm{X}$ and $\mathrm{Y}$ will all fall in layover. (b) Shadow occurs when the topographic feature blocks the radar signal from reaching areas on the backslope of a feature; in this scenario, the ground area between $X$ and $Y$ would be in shadow.

\section{Results and Discussion}

\subsection{Effect of Layover and Shadow}

Ascending and descending satellite imagery are acquired from different positions in space and, therefore, illuminate different areas on the ground so that the areas affected by layover and shadow are different. In other words, an area in shadow in the ascending pass might be illuminated in the descending pass and vice versa. Within the Lake Sarez study area, from the geometry of tracks $\mathrm{N}^{\circ} 5$ and $\mathrm{N}^{\circ} 100,23 \%$ and $46 \%$ of the area on the ground, respectively, is occluded by either layover or shadow. Much of this difference between the two tracks is accounted for by the lack of shadow areas in the descending track, a consequence of a smaller incidence angle and the specific viewing geometry. The distribution of layover and shadow areas in each case is shown in Figure 3.

For Lake Sarez, it is clear that the descending geometry would be the best choice in terms of coverage if SAR data from only one track was available, with $77 \%$ of the ground able to be surveyed compared to $54 \%$ for the ascending track. However, there are still significant areas of slope on the lakeshore that would be excluded from the analysis if only the descending track was available. A potential solution to the lack of coverage from any single geometry is to combine the two geometries, in some way, to create a synergistic effect. This is certainly possible and, in this case, the coverage is increased to $88 \%$ of the land surface by combining the individual geometries, in doing so covering most of the slopes missing using the descending track only (Figure 4a).

Another possible analysis over such sites is to take areas that are mutually covered by the ascending and descending geometries and perform a stereo InSAR analysis, to separate out the Up-Down and East-West components of motion [50]. In this case, the potential area available for a stereo survey is only $32 \%$ of the total land surface (Figure $4 \mathrm{~b}$ ). Although the benefits of a stereo survey are manifold, it may be that, in this case, critically hazardous areas could be excluded from such an analysis. 

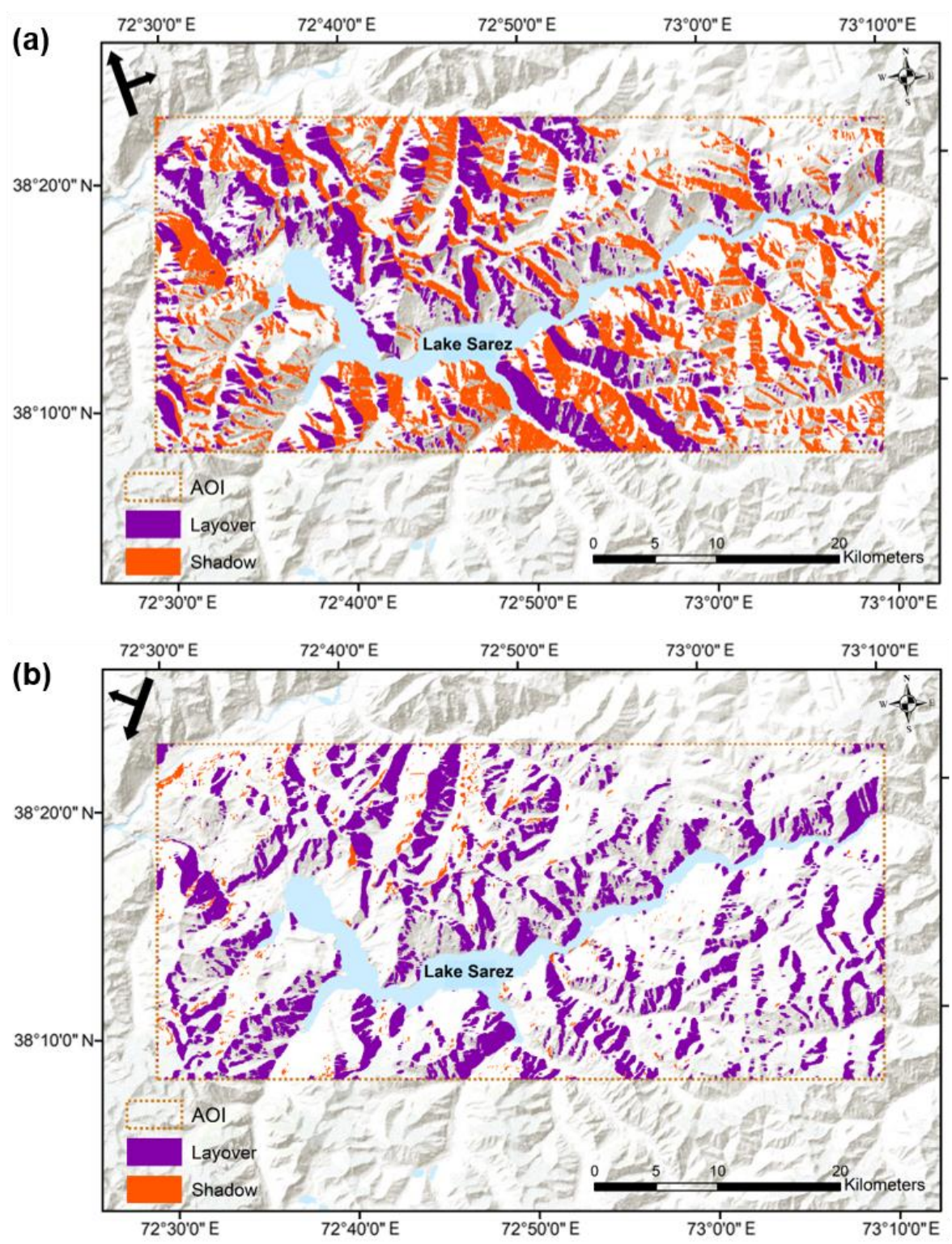

Figure 3. Areas of layover and shadow for the (a) ascending (track $\left.\mathrm{N}^{\circ} 100\right)$ and (b) descending (track $\mathrm{N}^{\circ}$ 5) geometries.

For ground motion hazard monitoring in the Lake Sarez area, it is possible to conclude that it would be more advantageous to perform separate interpretations of the ascending and descending pass surveys where, in combination, $88 \%$ of the area can be assessed, instead of a stereo analysis where only $32 \%$ coverage is possible. A broader conclusion would be that, in high mountain terrain, data from both ascending and descending tracks is needed to guarantee the fullest possible coverage over steep slopes. However, opposite pass surveys are not always possible due to a lack of data in some parts of the world. For instance, the Sentinel-1 mission prioritises stereo (ascending and descending) surveys over Europe and tectonically active areas only, in order to support scientific and policy objectives, and so routine access to both ascending and descending acquisitions cannot be relied upon. Other SAR satellites are available, but these are usually at a premium, meaning that obtaining a pair of InSAR stacks over an area using such data may not be as cost-effective. 

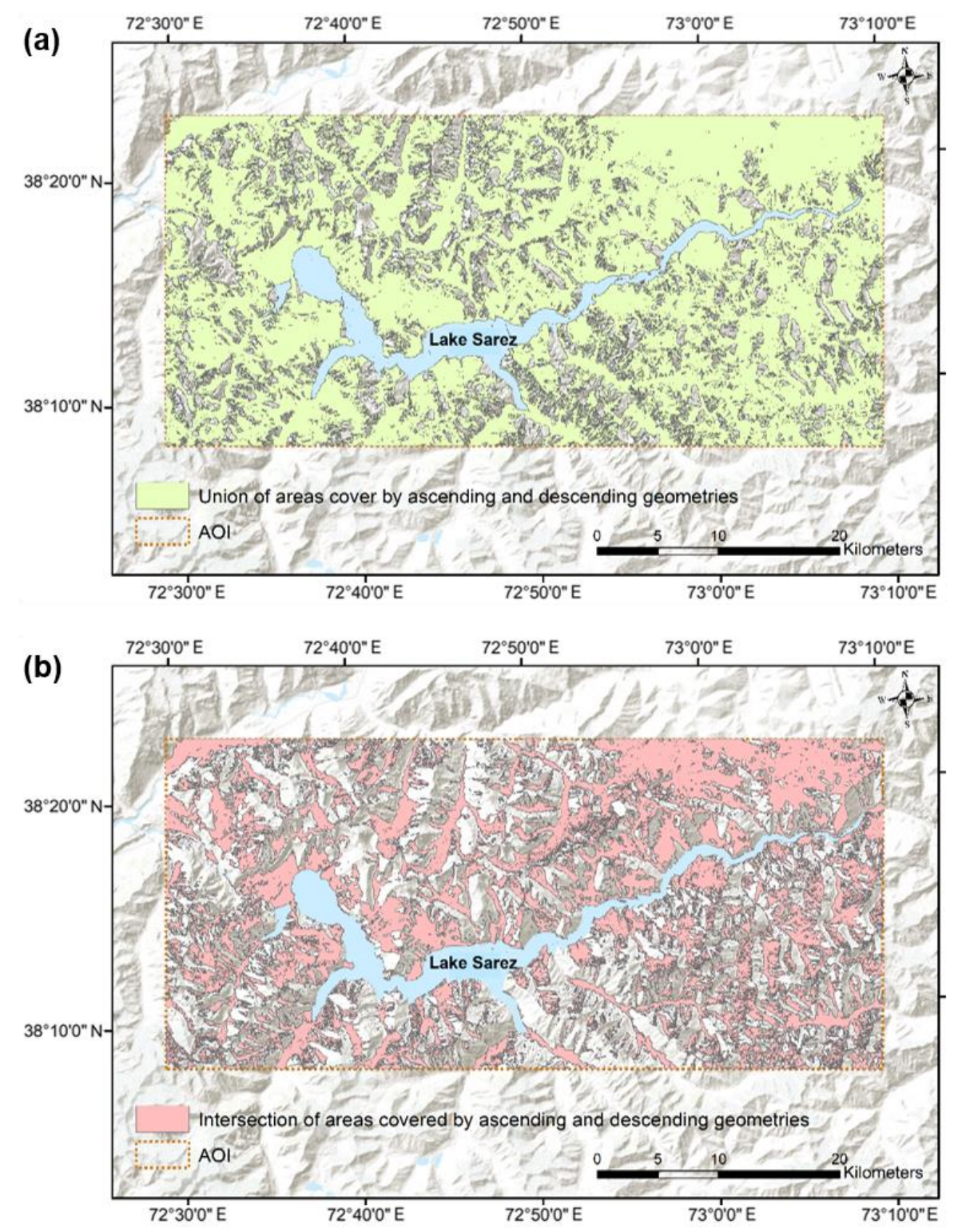

Figure 4. The coverage based on (a) combining the ascending and descending track geometries, and (b) the area common to both tracks.

The significant difference between the coverage of the ascending and descending geometries illustrates the importance of the incident geometry and the specific slope and aspect of the terrain. If there are multiple options for surveying an area, via a choice of different satellites and geometries, a simple apriori estimation of the layover and shadow may, therefore, help to determine which of those are optimal for a given location. Although a full simulation, as performed in this study, is necessary to completely delineate layover and shadow, estimating it using an approximate geometry is sufficient to identify the potential problems in achieving adequate coverage. This can be readily performed in a Geographic Information System (GIS) environment using only an estimate of the radar incident geometry and a DEM [42].

\subsection{Ground Motion}

For each InSAR method and track, the following ground motion products were generated at 20-m resolution: (i) the average line-of-sight (LOS) velocity for each pixel over the 2017-2019 period of observation; (ii) a time-series of ground motion throughout the same period of observation. The former assumes a linear model of deformation, whereas 
the latter determines the relative change in LOS displacement between each SAR image acquisition assuming a non-linear model of deformation.

Ground motion is measured in the satellite LOS, which varies $29-46^{\circ}$ from the surface normal across the swath from the near-to-far range. It should be noted that results from opposing geometries can appear to contradict each other. For example, the motion of an area of ground towards the satellite in the ascending data and might appear as motion away from the satellite in the descending data. However, this is simply a consequence of the side-looking geometry of the satellite, incidence angles, and steep topography (see Figure 5).

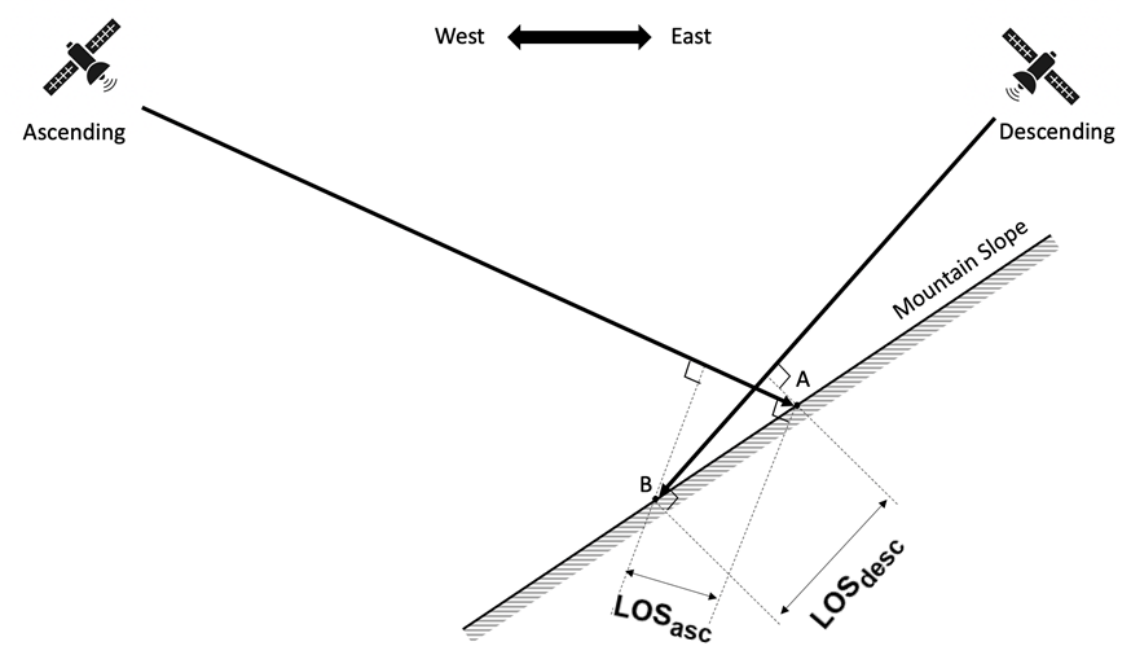

Figure 5. Line-of-sight (LOS) motion on a west-facing slope viewed from opposing geometries. Should point A move downslope to point B between acquisitions, the ascending data would register

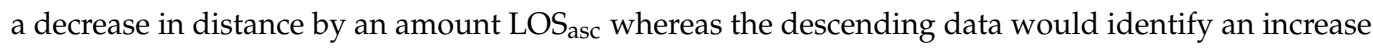
of $\operatorname{LOS}_{\text {desc }}$. Owing to the imaging geometry, $\operatorname{LOS}_{\mathrm{asc}}<\operatorname{LOS}_{\mathrm{desc}}$ meaning that the descending data is much more sensitive to changes.

The difference in coverage between the conventional SBAS method and the ISBAS method for the western part of the study area is illustrated in Figure 6. Owing to only sparse vegetation, both techniques provide reasonable coverage of measurements over the site and identify areas that appear to be in significant motion. However, there are some significant gaps in the coverage of the SBAS results when compared to the ISBAS survey. The coverage and measurement densities for the different approaches, excluding layover and shadow areas, are shown in Table 2. Providing more than double the spatial coverage, it is clear that the ISBAS survey is superior to the SBAS method in being able to provide ubiquitous coverage of all visible slopes in the Lake Sarez area. This concurs with the observations of studies in other regions (e.g., [44]) and can be attributed to the intermittent nature of coherence associated with land cover types, such as vegetation and snow cover, that vary over time. With this in mind, only the ISBAS results will be considered from this point onwards. 

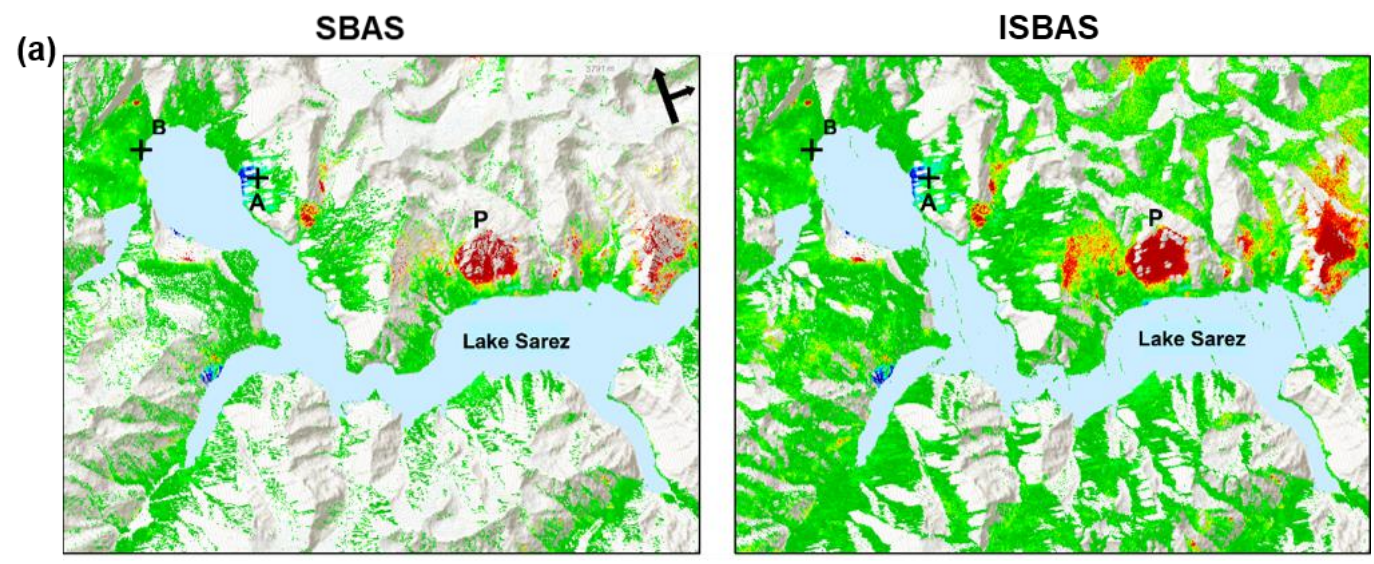

(b)

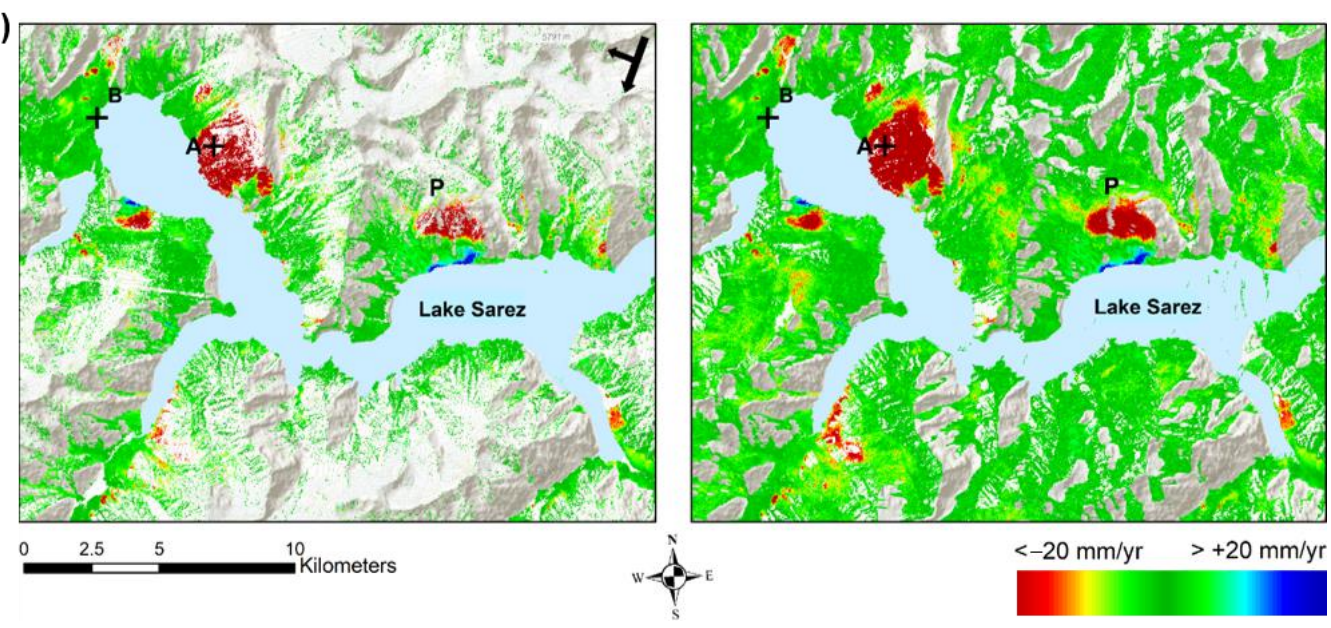

Figure 6. A comparison of the coverage between the SBAS and ISBAS methods for (a) ascending (track $\left.\mathrm{N}^{\circ} 100\right)$ and (b) descending (track $\mathrm{N}^{\circ}$ 5) geometries for the western part of the study area. Layover and shadow areas have been excluded. Average motion derived is colour-coded, with red indicating motion away from the sensor and blue towards the sensor. Points A, B and P identify features of interest referred to in the text.

Table 2. Coverage and density of ground motion measurements from the two tracks and InSAR methods across the study area, with areas of layover and shadow excluded.

\begin{tabular}{cccc}
\hline Track & InSAR Method & Coverage (\%) & $\begin{array}{c}\text { Average Measurement } \\
\text { Density (Pixels Per } \mathbf{~ k m}^{2} \text { ) }\end{array}$ \\
\hline Ascending $\left(\mathrm{N}^{\circ}\right.$ 100) & SBAS & 44 & 1100 \\
& ISBAS & 100 & 2500 \\
Descending $\left(\mathrm{N}^{\circ}\right.$ 5) & SBAS & 35 & 875 \\
& ISBAS & 100 & 2500 \\
\hline
\end{tabular}

Figure 7 shows the ISBAS average velocities from both geometries, and it can be seen that the wider surroundings of Lake Sarez are very dynamic. In this figure, the blue colour indicates motion towards the sensor and red away. Additionally, in this case, the ascending geometry (Figure 7a) is viewing from the left and the descending (Figure 7b) from the right. With a few exceptions, the observed motion can be predominantly attributed to mass movements down the steep slopes. 

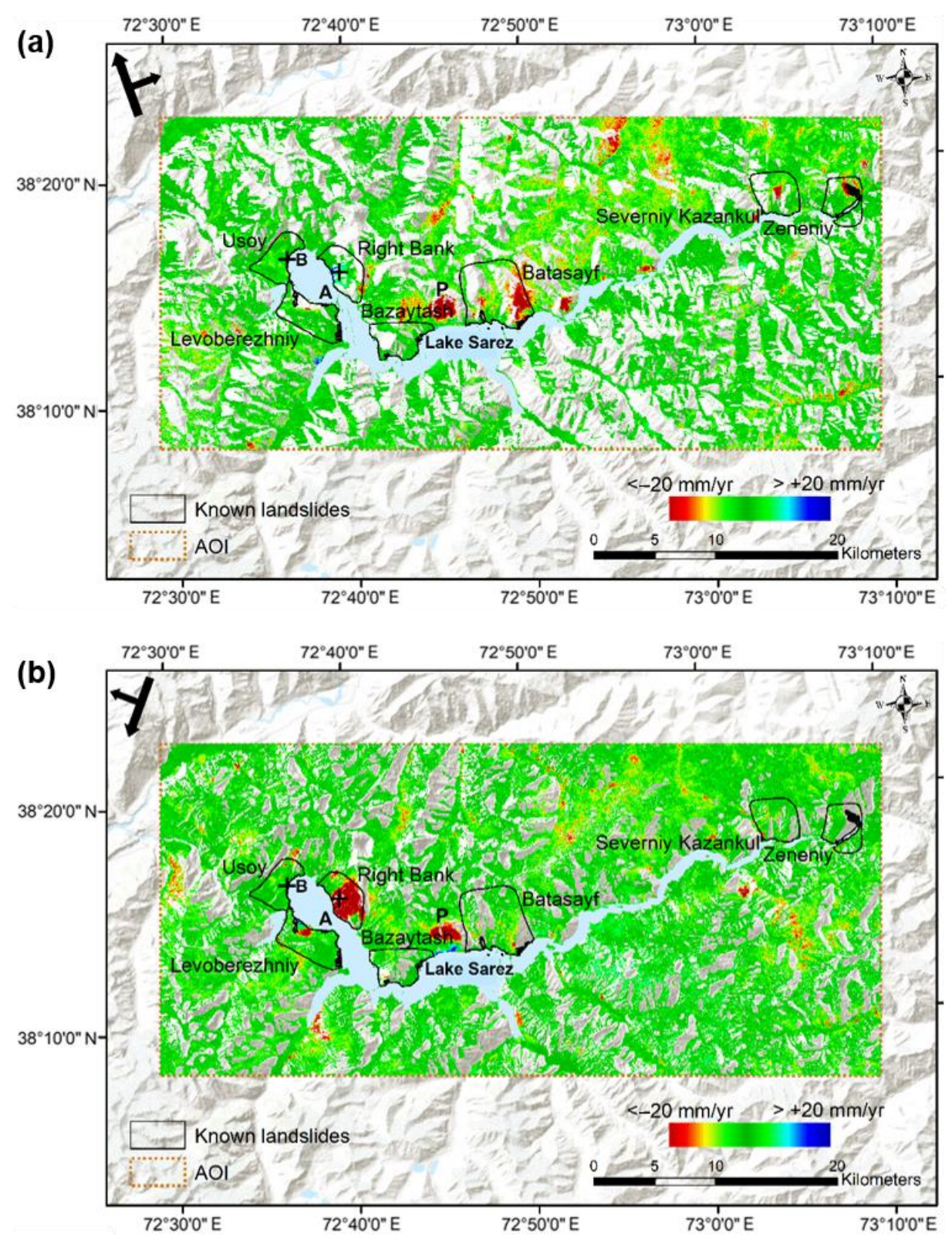

Figure 7. ISBAS average velocities as calculated from the (a) ascending (track $\left.\mathrm{N}^{\circ} 100\right)$ and (b) descending (track $\mathrm{N}^{\circ}$ ) geometries. Known landslide areas are indicated (after [8]). Points A, B and P identify features of interest referred to in the text.

A notable observation is that there is very little motion towards the sensor (i.e., blue) in either ground motion map. This is in part due to the presence of layover, which may obscure foreslopes, but may also be due to the fact that the sensor is less sensitive to motion on foreslopes than backslopes. This is because it takes a larger amount of motion on a foreslope to elicit the same LOS change seen by a small shift on the backslope. This is clear from Figure 5, where the same motion down a west-facing slope elicits a larger signal in the descending pass than the ascending pass.

Considering the known landsliding areas (adapted from [12] and shown in Figure 7), motion is observed within most of those locations, but not in both ascending and descending geometries simultaneously. On the whole, this is due to occlusion by layover and shadow in one result or the other.

Other significant landsliding areas are also observed outside of the known locations. One of these is a large area on the north shore that appears in both surveys, between 
the Bazaytash and Batasayf landslide areas (indicated as location P in Figures 6 and 7). This motion occurs on a steep south-facing slope that is not subject to significant layover or shadow. The observation that this area is subject to motion away from the sensor in both surveys implies that there is no strong lateral motion and the downward motion of the landslide is far greater than its motion towards the sensor in either of the viewing geometries. In fact, the presumption that this is a landslide can only be made based on the fact that it occurs on a steep slope, not from any notion of lateral motion. This illustrates a major drawback with the use of satellite InSAR from a single platform in a polar orbit; ascending and descending geometries may not detect the lateral movement of landslides on the north- or south-facing slopes as there will be little motion in the LOS direction. Possible solutions to this may be the integration of observations from different satellite platforms [8,51] or using the multi-aperture interferometry (MAI) technique [52].

Time-series of ISBAS-derived measurements corresponding to points A and B (locations indicated in Figures 6 and 7) are shown in Figures 8 and 9. Point A is located on the Right Bank landslide (also known as the Pravoberezhniy landslide), which has an area of around $3 \mathrm{~km}^{2}$ and lies approximately $5 \mathrm{~km}$ east of the Usoy Dam. This is an unstable slope with numerous cracks that has attracted the attention of researchers since the beginning of Lake Sarez investigations [12]. Cracks on the slope have been monitored for many years and the main landslide area was recorded as experiencing movement of up to $100 \mathrm{~mm} /$ year between 1985 and 1990 [53]. Significant downslope movement ( $47 \mathrm{~mm} /$ year on average) is clearly detectable using InSAR (Figures 7 and 8), with motion on parts of the mass reaching a maximum velocity of $105 \mathrm{~mm} /$ year. This is in accordance with localised field measurements of 10-20 mm/year [22] and ENVISAT-derived InSAR measurements up to $120 \mathrm{~mm}$ /year [35], both made during the period 1998-2006. Moreover, this supports the notion that the rate of movement on the Right Bank has been constant over the past $15-20$ years. It is also noted that the motion, although clear from both geometries, has a smaller range and is noisier in the ascending geometry, which again illustrates the above discussion regarding the relative lack of sensitivity over foreslopes.
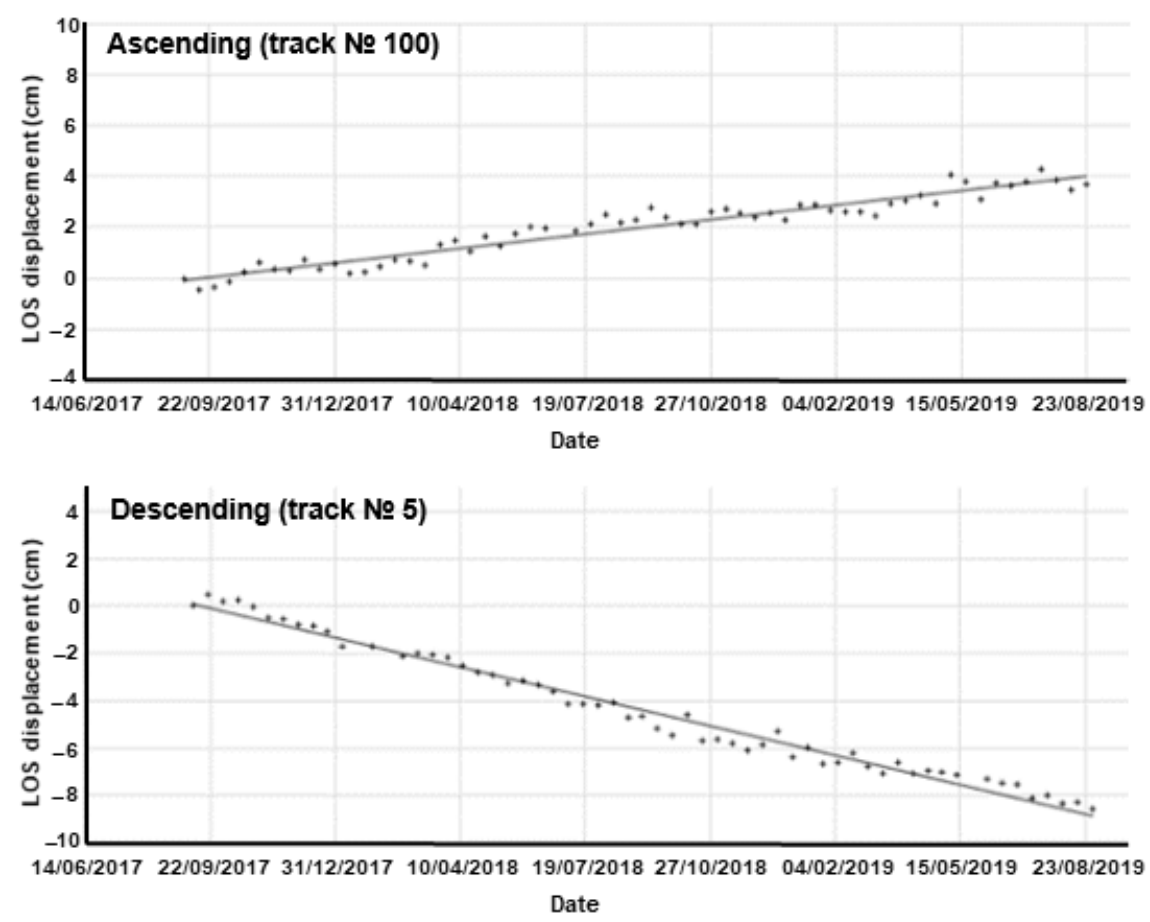

Figure 8. Time-series of ISBAS-derived cumulative LOS ground displacement for point A (indicated in Figure 6), the Right Bank landslide (also known as the Pravoberezhniy landslide). 

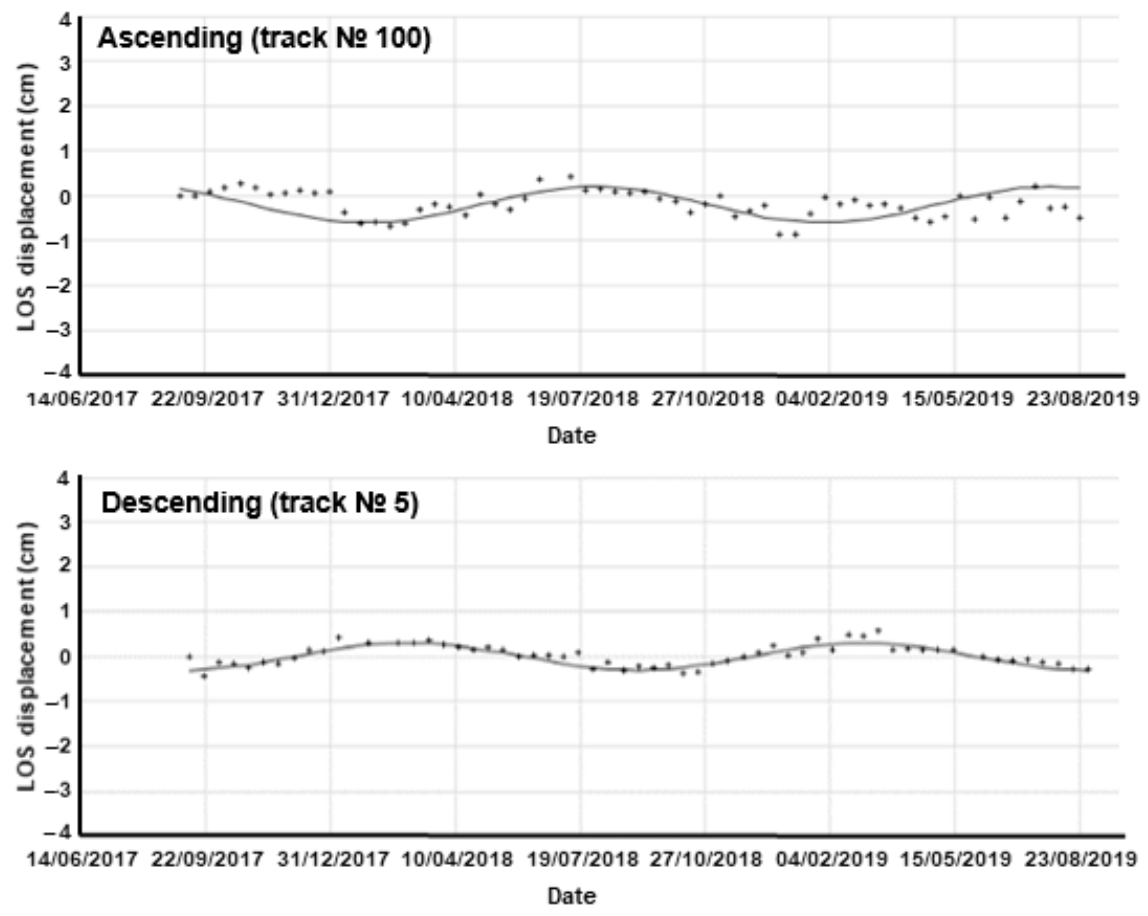

Figure 9. Time-series of ISBAS-derived cumulative LOS ground displacement for point B (indicated in Figure 6), the Usoy Dam.

Point B is situated on the Usoy Dam. The Usoy Dam is generally regarded as being stable, with reports of contemporary surface displacements not exceeding 5-10 mm/year [17]. This is corroborated by the time-series shown in Figure 9, which reveals a general trend of stability overprinted with a clear seasonal effect, with displacements of up to $\sim 8 \mathrm{~mm}$ between spring and autumn. This motion is likely attributable to either the varying hydrostatic load of the lake acting on the dam or changes in the internal pore water pressure [53] which will vary with the seasonal rise and fall of the water level. This may be as much as $12 \mathrm{~m}$ for Lake Sarez [54], coinciding with the behavior of lake levels across the Himalayas where peak levels usually occur in the summer months when there is a higher amount of precipitation [55]. The rise and fall of point B are in opposite sense in the ascending and descending data, which strongly indicates that this motion is much more lateral than vertical. This concurs with the suggestion of a sub-horizontal $\left(25^{\circ}\right)$ surface beneath the dam by Hanisch and Söder [53], and implies that the observed motion is most likely attributable to the higher horizontal water load forcing the dam away from the centre of the lake in the summer and its subsequent rebound in the winter when the lake level is at its lowest.

\section{Conclusions}

The aim of this study was to evaluate the application of InSAR to remotely monitoring ground motion in high mountain terrain, where steep topography, variations in snow cover, and general inaccessibility combine to make conventional surveying extremely challenging.

Using the Lake Sarez area in Tajikistan as a case study, two stacks of Sentinel-1 data from ascending and descending image geometries were processed, demonstrating that both surveys were severely affected by layover and shadow. Indeed, if focussing on areas that were mutually visible in both geometries, it was found that only $32 \%$ of the total ground area could be covered. The proportion of ground that was cumulatively covered by the geometries was much higher at $88 \%$, and much higher than either the ascending or descending coverage alone, which was calculated to be $54 \%$ and $77 \%$, respectively. If available, it is clear that both geometries should be interpreted separately to ensure the maximum possibility of identifying ground motion associated with geohazards in mountainous areas. This was also reinforced by the observation that neither of the geometries 
was singly able to identify all of the potential landslides whereas, in combination, the prospect was maximised.

Regarding snow cover, the effect that even sporadic cover can have upon a conventional InSAR method could be severely limiting in achieving a detailed and comprehensive survey across the landscape. The Lake Sarez area is affected by variable snow cover in the winter months only, and then to an extent of only around $60 \%$. This did not preclude the application of the APSIS ${ }^{\mathrm{TM}}$ implementation of the ISBAS technique and, from the extent of the average motion maps and the time-series that were produced, did not appear to affect the results at all. Indeed, the method was shown to provide $100 \%$ coverage of the area not precluded by layover and shadow, which is more than double the amount possible using a conventional SBAS technique. While the coverage obtainable using an SBAS approach may be improved through careful selection of a temporal subset of SAR images not containing snow, the ISBAS method can be readily applied to the entire SAR stack due to its built-in consideration of intermittent coherence.

The result obtained using the ISBAS method confirm the occurrence of ground motion across landslide areas identified in previous studies, agreeing in terms of the extent and direction of motion, and rates measured in the field and in previous InSAR studies. Importantly, this was achieved at high resolution $(20 \mathrm{~m})$ using freely available Sentinel-1 data, without recourse to any ground survey data, and without having to install corner reflectors or alike in the field. Notable areas of ground motion included the Right Bank (Pravoberezhniy) landslide, with rates of up to $105 \mathrm{~mm} /$ year. In contrast, the Usoy Dam was found to be stable overall, but with seasonal displacements of up to $\sim 8 \mathrm{~mm}$ between spring and autumn.

Monitoring high mountain terrain with EO data can be challenging, especially when using SAR data with an oblique viewing angle. However, as demonstrated here, extreme variations in topography, inaccessibility, and snow cover are not a barrier to the acquisition of dense measurements of ground motion as long as an appropriate InSAR method is utilised. Furthermore, an operational satellite mission acquiring data from ascending and descending geometries, such as Sentinel-1, with a good archive and a secure plan for the future provides a strong basis for a cost-effective routine remote and high-resolution monitoring system for geohazards in mountainous regions.

Author Contributions: Conceptualization, A.S. and S.G.; methodology, D.G., A.A. and R.G.; formal analysis, A.S., D.G. and A.A.; writing—original draft preparation, A.S., S.G. and B.D.1.B.-B.; writingreview and editing, D.G., A.A., R.G., S.M. All authors have read and agreed to the published version of the manuscript.

Funding: This research received no external funding.

Institutional Review Board Statement: Not applicable.

Informed Consent Statement: Not applicable.

Data Availability Statement: The data used to support the findings of this study are included within the article.

Acknowledgments: This work was supported by the GeoEnergy Research Centre and Terra Motion Limited. The authors are grateful to the Copernicus programme for making the Sentinel-1 data freely available. The authors are also grateful to the three anonymous reviewers for their insightful comments and suggestions, which helped to improve the quality of this manuscript.

Conflicts of Interest: The authors declare no conflict of interest.

\section{References}

1. Keiler, M.; Knight, J.; Harrison, H. Climate change and geomorphological hazards in the eastern European Alps. Phil. Trans. R. Soc. A 2010, 368, 2461-2479. [CrossRef] [PubMed]

2. Kargel, J.S.; Leonard, G.; Crippen, R.; Delaney, K.; Evans, S.G.; Schneider, J. Satellite monitoring of Pakistan's Rockslide-Dammed Lake Gojal. Eos 2010, 91, 394-395. [CrossRef] 
3. Kreutzmann, H. After the flood: Mobility as an adaptation strategy in high mountain oases: The case of Pasu in Gojal, Hunza Valley, Karakoram. Die Erde 2012, 143, 49-73.

4. Cook, N.; Butz, D. Mobility justice in the context of disaster. Mobilities 2016, 11, 400-419. [CrossRef]

5. Kirschbaum, D.; Watson, C.S.; Rounce, D.R.; Shugar, D.H.; Kargel, J.S.; Haritashya, U.K.; Amatya, P.; Shean, D.; Anderson, E.R.; Jo, M. The state of remote sensing capabilities of cascading hazards over high mountain Asia. Front. Earth Sci. $2019,7,197$. [CrossRef]

6. Carlà, T.; Intrieri, E.; Raspini, F.; Bardi, F.; Farina, P.; Ferretti, A.; Colombo, D.; Novali, F.; Casagli, N. Perspectives on the prediction of catastrophic slope failures from satellite InSAR. Sci. Rep. 2019, 9, 14137. [CrossRef]

7. Sowter, A. Orthorectification and interpretation of differential InSAR data over mountainous areas: A case study of the May 2008 Wenchuan earthquake. Int. J. Remote Sens. 2010, 31, 3435-3448. [CrossRef]

8. Sun, Q.; Hu, J.; Zhang, L.; Ding, X. Towards slow-moving landslide monitoring by integrating multi-sensor InSAR time series datasets: The Zhouqu case study, Chine. Remote Sens. 2016, 8, 908. [CrossRef]

9. Zhao, C.; Lu, Z.; Zhang, C.; de la Fuente, J. Large-area landslide detection and monitoring with ALOS/PALSAR imagery data over Northern California and Southern Oregon, USA. Remote Sens. Environ. 2012, 124, 348-359. [CrossRef]

10. Wasowski, J.; Bovenga, F. Investigating landslides and unstable slopes with satellite Multi Temporal Interferometry: Current issues and future perspectives. Eng. Geol. 2014, 174, 103-138. [CrossRef]

11. Loibl, D.; Bookhagen, B.; Valade, S.; Schneider, C. OSARIS, the "Open Source SAR Investigation System" for automatized parallel InSAR processing of Sentinel-1 time series data with special emphasis on cryosphere applications. Front. Earth Sci. 2019, 7, 172. [CrossRef]

12. Abdullaev, U.; Abdullaev, S.; Blaha, P.; Akhmedov, A.; Khudobakhshova, G. The Usoy Dam, Lake Sarez and possibilities of geophysical methods. In Proceedings of the International Journal on Hydropower \& Dams, HYDRO 2011, Prague, Czech Republic, 17-19 October 2011.

13. Lukk, A.A.; Yunga, S.L.; Shevchenko, V.I.; Hamburger, M.W. Earthquake focal mechanisms, deformation state, and seismotectonics of the Pamir-Tien Shan region, Central Asia. J. Geophys. Res. 1995, 100, 20321-20343. [CrossRef]

14. Hergarten, C. Investigations on Land Cover and Land Use of Gorno Badakhshan (GBAO) by Means of Land Cover Classifications Derived from LANDSAT 7 Data Making Use of Remote Sensing and GIS Techniques. Master's Thesis, University of Bern, Bern, Switzerland, 2004.

15. Squires, V.R.; Safarov, N. Diversity of plants and animals in mountain ecosystems in Tajikistan. J. Rangel. Sci. 2013, 4, 43-61.

16. Elliott, A.; Elliott, J.; Hollingsworth, J.; Kulikova, G.; Parsons, B.; Walker, R. Satellite imaging of the 2015 M7.2 earthquake in the Central Pamir, Tajikistan, elucidates a sequence of shallow strike-slip ruptures of the Sarez-Karakul fault. Geophys. J. Int. 2020, 221, 1696-1718. [CrossRef]

17. Ischuk, A.R. Usoy natural dam: Problem of security (Lake Sarez, Pamir Mountains, Tadjikistan). Ital. J. Eng. Geol. Environ. 2006, 1, 189-192.

18. Metzger, S.; Schurr, B.; Ratschbacher, L.; Sudhaus, H.; Kufner, S.-K.; Schöne, T.; Zhang, Y.; Perry, M.; Bendick, R. The 2015 M ${ }_{w} 7.2$ Sarez strike-slip earthquake in the Pamir interior: Response to the underthrusting of India's western promontory. Tectonics 2017, 36, 2407-2421. [CrossRef]

19. Ambraseys, N.; Bilham, R. The Sarez-Pamir earthquake and landslide of 18 February 1911. Seismol. Res. Lett. 2012, 83, 294-314. [CrossRef]

20. Kulikova, G.; Schurr, B.; Krüger, F.; Brzoska, E.; Heimann, S. Source parameters of the Sarez-Pamir earthquake of 1911 February 18. Geophys. J. Int. 2016, 205, 1086-1098. [CrossRef]

21. Schuster, R.L.; Alford, D. Usoi landslide dam and Lake Sarez, Pamir Mountains, Tajikistan. Environ. Eng. Geosci. 2004, 10, 151-168. [CrossRef]

22. Alford, D.; Schuster, R.L. Introduction and summary. In Usoi Landslide Dam and Lake Sarez. An Assessment of Hazard and Risk in the Pamir Mountains, Tajikistan; Alford, D., Schuster, R.L., Eds.; United Nations: New York, NY, USA; Geneva, Switzerland, 2000; pp. $1-18$.

23. Middleton, R.; Thomas, H. Tajikistan and the High Pamirs: A Companion and Guide, 1st ed.; Odyssey Publications: Hong Kong, China, 2008; p. 700.

24. Bolt, B.A.; Horn, W.L.; MacDonald, G.A.; Scott, R.F. Geological Hazards: Earthquakes—Tsunamis—Volcanoes—Avalanches-LandslidesFlood; Springer: Berlin/Heidelberg, Germany, 2013; p. 330.

25. Stone, R. Peril in the Pamirs. Science 2009, 326, 1614-1617. [CrossRef] [PubMed]

26. Kiersch, G.A. Vaiont reservoir disaster. Civ. Eng. 1964, 34, 32-39.

27. Rosen, P.A.; Hensley, S.; Joughin, I.R.; Li, F.K.; Madsen, S.N.; Rodríguez, E.; Goldstein, R.M. Synthetic aperture radar interferometry. Proc. IEEE 2000, 88, 333-382. [CrossRef]

28. Gabriel, A.K.; Goldstein, R.M.; Zebker, H.A. Mapping small elevation changes over large areas: Differential radar interferometry. J. Geophys. Res. 1989, 94, 9183-9191. [CrossRef]

29. Osmanoğlu, B.; Sunar, F.; Wdowinski, S.; Cabral-Cano, E. Time series analysis of InSAR data: Methods and trends. ISPRS J. Photogramm. Remote Sens. 2016, 115, 90-102. [CrossRef]

30. Ferretti, A.; Colesanti, C.; Perissin, D.; Prati, C.; Rocca, F. Evaluating the effect of the observation time on the distribution of SAR permanent scatterers. In Proceedings of the Fringe, Frascati, Italy, 1-5 December 2003. 
31. Crosetto, M.; Monserrat, O.; Cuevas-González, M.; Devanthéry, N.; Crippa, B. Persistent scatterers interferometry: A review. ISPRS J. Photogramm. Remote Sens. 2016, 115, 78-89. [CrossRef]

32. Snehmani, M.K.S.; Gupta, R.D.; Bhardwaj, A.; Joshi, P.K. Remote sensing of mountain snow using active microwave sensors: A review. Geocarto Int. 2015, 30, 1-27. [CrossRef]

33. Baduge, A.W.A.; Henschel, M.D.; Hobbs, S.; Buehler, S.A.; Ekman, J.; Lehrbass, B. Seasonal variation of coherence in SAR interferograms in Kiruna, Northern Sweden. Int. J. Remote Sens. 2016, 37, 370-387. [CrossRef]

34. Maskey, S.; Uhlenbrook, S.; Ojha, S. An analysis of snow cover changes in the Himalayan region using MODIS snow products and in-situ temperature data. Clim. Change 2011, 108, 391-400. [CrossRef]

35. Droz, P.; Fumagalli, A.; Novali, F.; Young, B. GPS and InSAR technologies: A joint approach for the safety of Lake Sarez. In Proceedings of the IVth Canadian Conference on Geohazards, Quebec, QC, Canada, 20-24 May 2008.

36. Lazecky, F.; Comut, F.C.; Nikolaeva, E.; Bakon, M.; Papco, J.; Ruiz-Armenteros, A.M.; Qin, Y.; de Souza, J.J.M.; Ondejka, P. Potential of Sentinel-1a for nation-wide routine updates of active landslide maps. ISPRS Int. Arc. Photogramm. Remote Sens. Spatial Inf. Sci. 2016, XLI-B7, 775-781. [CrossRef]

37. Ferretti, A.; Prati, C.; Rocca, F. Permanent scatterers in SAR interferometry. IEEE Trans. Geosci. Remote Sens. 2001, 39, 8-20. [CrossRef]

38. Berardino, P.; Fornaro, G.; Lanari, R.; Sansosti, E. A new algorithm for surface deformation monitoring based on small baseline differential SAR interferograms. IEEE Trans. Geosci. Remote Sens. 2002, 40, 2375-2383. [CrossRef]

39. Sowter, A.; Bateson, L.; Strange, P.; Ambrose, K.; Syafiudin, M.F. DInSAR estimation of land motion using intermittent coherence with application to the South Derbyshire and Leicestershire coalfields. Remote Sens. Lett. 2013, 4, 979-987. [CrossRef]

40. Sowter, A.; Amat, M.B.C.; Cigna, F.; Marsh, S.; Athab, A.; Alshammari, L. Mexico City land subsidence in 2014-2015 with Sentinel-1 IW TOPS: Results using the Intermittent SBAS (ISBAS) technique. Int. J. Appl. Earth Obs. Geoinf. 2016, 52, 230-242. [CrossRef]

41. Gee, D.; Sowter, A.; Novellino, A.; Marsh, S.; Gluyas, J. Monitoring land motion due to natural gas extraction: Validation of the intermittent SBAS (ISBAS) DInSAR algorithm over gas fields of North Holland, the Netherlands. Mar. Pet. Geol. 2016, 77, 1338-1354. [CrossRef]

42. Cigna, F.; Bateson, L.; Jordan, C.; Dashwood, C. Simulating SAR geometric distortions and predicting Persistent Scatterer densities for ERS-1/2 and ENVISAT C-band SAR and InSAR applications: Nationwide feasibility assessment to monitor the landmass of Great Britain with SAR imagery. Remote Sens. Environ. 2014, 152, 441-466. [CrossRef]

43. Schiller, A.; Vecchiotti, F.; Amabile, A.S.; Guardiani, C.; Dhital, M.R.; Dhakal, A.; Pant, B.R.; Ostermann, M.; Supper, R. Ground motion and PSI density analysis from Envisat and Sentinel1a InSAR data in the context of a complex landslide monitoring strategy in Karnali river basin, Far-Western Nepal. In Proceedings of the 22nd EGU General Assembly, EGU2020-21875, Online, 4-8 May 2020.

44. Cigna, F.; Sowter, A. The relationship between intermittent coherence and precision of ISBAS InSAR ground motion velocities: ERS-1/2 case studies in the UK. Remote Sens. Environ. 2017, 202, 177-198. [CrossRef]

45. Novellino, A.; Cigna, F.; Sowter, A.; Ramondini, M.; Calcaterra, D. Exploitation of the Intermittent SBAS (ISBAS) algorithm with COSMO-SkyMed data for landslide inventory mapping in north-western Sicily, Italy. Geomorphology 2017, 280, 153-166. [CrossRef]

46. Sowter, A.; Athab, A.; Novellino, A.; Grebby, S.; Gee, D. Supporting energy regulation by monitoring land motion on a regional and national scale: A case study of Scotland. Proc. IMechE Part A J. Power Energy 2018, 232, 85-99. [CrossRef]

47. Grebby, S.; Sowter, A.; Gluyas, J.; Toll, D.; Gee, D.; Athab, A.; Girindran, R. Advanced analysis of satellite data reveals ground deformation precursors to the Brumadinho Tailings Dam collapse. Commun. Earth Environ. 2021, 2, 2. [CrossRef]

48. Farr, T.G.; Rosen, P.A.; Caro, E.; Crippen, R.; Duren, R.; Hensley, S.; Kobrick, M.; Paller, M.; Rodriguez, E.; Roth, L.; et al. The shuttle radar topography mission. Rev. Geophys. 2007, 45, RG2004. [CrossRef]

49. Schreier, G. SAR Geocoding: Data and Systems; Wichmann: Karlsruhe, Germany, 1993; p. 435.

50. Pepe, A.; Calò, F. A review of interferometric synthetic aperture RADAR (InSAR) multi-track approaches for the retrieval of Earth's surface displacements. Appl. Sci. 2017, 7, 1264. [CrossRef]

51. Wright, T.; Parsons, B.; Lu, Z. Toward mapping surface deformation in three dimensions using InSAR. Geophys. Res. Lett. 2004, 31, L01607. [CrossRef]

52. Mastro, P.; Serio, C.; Masiello, G.; Pepe, A. The multiple aperture interferometry (MAI) technique for the detection of large ground displacement dynamics: An overview. Remote Sens. 2020, 12, 1189. [CrossRef]

53. Hanisch, J.; Söder, C.-O. Geotechnical assessment of the Usoi landslide dam and the right bank of Lake Sarez. In Usoi Landslide Dam and Lake Sarez. An Assessment of Hazard and Risk in the Pamir Mountains, Tajikistan; Alford, D., Schuster, R.L., Eds.; United Nations: New York, NY, USA; Geneva, Switzerland, 2000; pp. 23-42.

54. United Nations International Strategy for Disaster Reduction. Sarez Lake: The Latest Achievements and Unsolved Problems; United Nations Office for Disaster Risk Reduction: Dushanbe, Tajikistan, 2007; p. 17.

55. Zou, F.; Tenzer, R.; Jin, S. Water storage variations in Tibet from GRACE, ICESat and hydrological data. Remote Sens. 2019, 11, 1103. [CrossRef] 